\title{
Developing Learning Objects for Secondary School Students: A Multi-Component Model
}

\author{
Robin Kay and Liesel Knaack \\ University of Ontario, Institute of Technology, \\ Oshawa, Ontario, Canada
}

robin.kay@uoit.ca liesel.knaack@uoit.ca

\begin{abstract}
Previous research on the development of learning objects have three notable characteristics: a focus on either technical or learning features, but not both, a target audience consisting exclusively of higher education students, and the absence of formal evaluation. This study provides a detailed description and formal evaluation of a multi-component model used to develop five learning objects for secondary school students. Overall, two thirds of the students reported that the learning objects were beneficial, citing a motivating theme, interactivity, and visual qualities as the most important features. However, almost $60 \%$ of all students were critical about the learning object quality. Clarity of instructions, help functions and organization/layout presented the most problems. While the development model used in the study emphasized both technical and learning components, the latter was far more important to teachers and students. Key steps that appeared to be beneficial in the development process included a collaborative team approach, understanding the learner, a focus on clear instruction and organization, and using a comprehensive, theoretically supported evaluation metric to examine the quality and benefits of learning objects.
\end{abstract}

Keywords: Development, evaluation, secondary school, learning object

\section{Introduction}

Over the past five years, the educational potential of learning objects has been examined in some detail, however, relatively little research has been done looking at developmental process. A review of 58 articles (Kay \& Knaack, 2006) revealed only five papers that documented the process of developing a learning object (Bradley \& Boyle, 2004; Cochrane, 2005; Krauss \& Ally, 2005; MacDonald et al., 2005; Metros, 2005). Three patterns emerged from these studies. First, only higher education students have been looked at. Second, technical features are emphasized ahead of learning features. Third, there is a clear absence of systematic formal evaluation. The purpose of this study was to document and formally evaluate a pedagogically guided model of developing learning objects for secondary school

Material published as part of this journal, either on-line or in print, is copyrighted by the publisher of the Interdisciplinary Journal of Knowledge and Learning Objects. Permission to make digital or paper copy of part or all of these works for personal or classroom use is granted without fee provided that the copies are not made or distributed for profit or commercial advantage AND that copies 1) bear this notice in full and 2) give the full citation on the first page. It is permissible to abstract these works so long as credit is given. To copy in all other cases or to republish or to post on a server or to redistribute to lists requires specific permission and payment of a fee. Contact Publisher@ijklo.org to request redistribution permission. students.

In order to fully understand the model used in this study, a clear definition of learning objects will be established, followed by an analysis of previous research on the development of learning objects, and finally, an examination of the design principles used in past studies. The primary goals of this paper are to (a) examine a new popu- 
lation for using learning objects, (b) describe a multi-component development model based on a composite of key features examined previously, and (c) formally evaluate the key qualities of learning objects that appear to have an impact on learning.

\section{Literature Review}

\section{Definition of Learning Object}

In order to critically examine the design and development of learning objects, a clear definition is necessary. Considerable effort has been directed toward this goal (Agostinho, Bennett, Lockyer \& Harper, 2004; Butson, 2003; Friesen, 2001; Gibbons, Nelson \& Richards, 2002; Littlejohn, 2003; McGreal, 2004; Metros, 2005; Muzio, Heins \& Mundell, 2002; Parrish, 2004; Polsani, 2003; Wiley, 2000; Wiley, et al., 2004), however consensus has yet to be reached.

Two definition pathways have been pursued by learning object theorists. The original "technology-focussed" pathway was founded on an object-oriented programming model. A learning object was seen as a discrete, reusable, context-free learning chunk (e.g., Baruque \& Melo, 2004; Downes, 2003; Hamel \& Ryan-Jones, 2002; Parrish, 2004; Siqueira, Melo, \& Braz, 2004). In theory, this kind of definition leads to a cost-efficient, well-organized, searchable repository of learning objects that can be used for a variety of purposes. The object-oriented definition has dominated the design and development of learning objects over the past five years (Butson, 2003; Gibbons et al, 2000; Wiley, et al. 2004).

A second "learning-focussed" pathway to defining learning objects emerged as a reaction to an overemphasis of technological characteristics. Butson (2003) claimed that learning objects, as defined by object-oriented theorists, were actually hindering instruction by reducing learning to small chunks and taking the meaning and holistic nature of discovery out of education. He advocated a more open-ended, context-based, non-prescriptive design. A number of other researchers and designers advocate a more learning-focused framework for the design of learning objects (Baruque \& Melo, 2004; Bradley \& Boyle, 2004; Cochrane, 2005; Wiley et al., 2004).

Both technical and learning-based definitions offer important qualities that can contribute to the success of learning objects. With respect to a technologically guided definition, key features include accessibility, ease of use, and reusability. Making learning objects readily accessible over the web helps address the difficulties teachers experience in acquiring the latest versions of educational software. Well over $90 \%$ of all public schools in North America and Europe now have access to the Internet (and therefore learning objects) with most having high-speed broadband connections (Compton \& Harwood, 2003; McRobbie, Ginns, \& Stein, 2000; Plante \& Beattie, 2004; US Department of Education, National Center for Education Statistics, 2002). Therefore, it makes sense to design learning objects to be delivered through the Internet. In addition, limiting the focus and size of learning objects increases ease of use and makes them much more attractive to busy educators who have little time to learn more complex, advanced software packages (Gadanidis, Gadanidis, \& Schindler, 2003). Finally, reusability permits learning objects to be useful for a large audience, particularly when the objects are placed in well organized, searchable databases (e.g., Agostinho et al., 2004; Duval, Hodgins, Rehak \& Robson, 2004; Rehak \& Mason, 2003).

With respect to enhancing learning, many learning objects are interactive tools that support exploration, investigation, constructing solutions, and manipulating parameters instead of memorizing and retaining a series of facts. The success of this constructivist based model is well documented (e.g., Albanese \& Mitchell, 1993; Bruner, 1983, 1986; Carroll, 1990; Caroll \& Mack, 1984; Collins, Brown, \& Newman, 1989; Vygotsky, 1978). In addition, a number of learning objects have a graphical component that helps make abstract concepts more concrete (Gadanidis et al., 
2003). Furthermore, certain learning objects allow students to explore higher level concepts by reducing cognitive load. They act as perceptual and cognitive supports, permitting students to examine more complex and interesting relationships (Sedig \& Liang, 2006). Finally, learning objects are adaptive, allowing users to have a certain degree of control over their learning environments, particularly "when" they are learning and for "how long".

In this study, key components of technical and learning-based definitions are used. Learning objects are as defined as "reusable, interactive web-based tools that support the learning of specific concepts by enhancing, amplifying, and guiding the cognitive processes of learners".

\section{Design of Learning Objects}

Somewhat predictably, the design of learning objects has mirrored the two definitions presented above. More technically inclined designers have emphasized accessibility (Downes, 2003), adaptability (Siqueira, et al., 2004), the effect use of metadata (Baruque \& Melo, 2004; Boyle, 2003; Hamel \& Ryan-Jones, 2002; Littlejohn, 2003), reusability (Cochrane, 2005; Downes, 2003; Hamel \& Ryan-Jones, 2002; Littlejohn, 2003; Muzio et al., 2002; Paquette \& Rosca, 2002; Siqueira, et al., 2004; Wiley et al., 2004) and standardization (Downes, 2003; Hamel \& RyanJones, 2002; Laurillard, 2002; Littlejohn, 2003; Polsani, 2003).

Pedagogically-focused designers of learning objects have emphasized principles of instructional design (Baruque \& Melo, 2004; Krauss \& Ally, 2005; MacDonald et al., 2005; Muzio et al., 2002), interactivity (Bradley \& Boyle, 2004; Cochrane, 2005; Sedig \& Liang, 2006), clear instructions (Cochrane, 2005), formative assessment (Bradley \& Boyle, 2004; Cochrane, 2005) and solid learning theory (Baruque \& Melo, 2004; Bradely \& Boyle, 2004; Cochrane, 2005; Wiley et al., 2004).

Two observations are worth noting in the literature on the design of learning objects. First, there is relatively little research on the design principles for learning objects (Cochrane, 2005; Williams, 2000). Recommendations for specific design characteristics are made but are rarely evaluated (Downes, 2003; Krauss \& Ally, 2005). Second, designers tend to bifurcate with respect to guiding frameworks emphasizing either a technical (Boyle, 2003; Bradley \& Boyle, 2004; Hamel \& Ryan-Jones, 2002; Laurillard, 2002; Littlejohn, 2003; Paquette \& Rosca, 2002; Petrinjak \& Graham, 2004; Polsani, 2003; Siqueira et al., 2004) or a learning-focussed (Baruque \& Melo, 2004; Cochrane, 2005; Krauss \& Ally, 2005; Muzio et al., 2002; Sedig \& Liang, 2006; Wiley et al., 2004) model, but not both.

In this study, an attempt has been made to merge the design goals of both technical and learningbased theorists. However, when there was a theoretical conflict between technical and learning philosophies, pedagogy principles took precedence.

\section{Development of Learning Objects}

Developing high quality learning objects is a daunting task involving collaboration among subject specialists, programmers, multimedia designers, and evaluators/researchers (Bradley \& Boyle, 2004; Cochrane, 2005; Krauss \& Ally, 2005; Metros, 2005; MacDonald et al., 2005; Polsani, 2003). Subject specialists are necessary to provide the instructional goals and perceptive of where the learning objects fits in the larger picture. Programmers work with the subject specialists and multimedia designers to translate ideas and written plans into a digital, interactive, motivating, and easy to use format. Finally researchers informally and formally assess the learning object, providing constructive feedback for future modifications.

A review of 58 articles (Kay \& Knaack, 2006) revealed only five papers that documented the process of developing a learning object (Bradley \& Boyle, 2004; Cochrane, 2005; Krauss \& Ally, 2005; Metros, 2005; MacDonald et al., 2005). All five studies developed learning objects for 
higher education students with a collaborative team which always included subject matter and technology specialists. In addition, all studies collected feedback from various users while the learning object was being designed. However, only three studies did a formal descriptive evaluation of the final learning object product (Cochrane, 2005; Krauss \& Ally, 2005; MacDonald et al., 2005). No studies did a comprehensive analysis of the impact of specific learning object qualities. In other words, while a number of design features, both technical and learning-based, have been incorporated by developers of learning objects, the impact of these features has not been formally tested.

This study followed the collaborative model of previous researchers, but added a formal, systematic evaluation metric to explore the relative contributions of specific design features.

\section{Purpose}

The purpose of this study was to examine the quality and perceived benefit of learning objects developed for secondary school students using a multi-component model that incorporated both technical and learning based features.

\section{Method}

\section{Overview}

The learning object development project was based on a partnership between the Faculty of Education and the University of Ontario Institute of Technology (UOIT) and the Centre for Learning and Teaching Through Technology (LT3) at the University of Waterloo (UW). The principle framework for development was derived from the Cooperative Learning Object Exchange (CLOE), a collaboration among Ontario universities and colleges focussed on the development, sharing and reuse of learning objects (see McGreal et al., 2004 for detailed description). This CLOE model (http://tlc.uwaterloo.ca/projects/cloe/CaseStory/) has been replicated many times and has proven effective in the design of learning objects for the CLOE repository (http://www.cloe.on.ca). A modified version of a five-day CLOE workshop designed for higher education was used to guide the development of learning objects for secondary school students.

\section{Team Members}

The key team members in this study were:

- An LT3 trainer to assist in the delivery of the CLOE workshop

- Preservice teacher candidates to assist in the organization, management, and development of learning objects

- Experienced teachers to provide subject matter expertise

- A UOIT Flash programmer and multimedia designer

- A member of the UOIT Faculty of Education to guide evaluation and research

In order to account for the additional workload required for the preservice teacher candidates, the entire project was counted as a course (Independent Study) on their transcripts. 


\section{Development Process}

\section{Overview}

The design, development and evaluation of the five learning objects took place over eight months. A timeline of the development process is presented in Table 1. A detailed description of each step follows.

Table 1: Key Steps and Timeline for Developing the Learning Objects

\begin{tabular}{|c|c|c|}
\hline Step & Time & Description \\
\hline Selecting Team Members & March 2004 & $\begin{array}{l}\text { Experienced teachers were contacted to } \\
\text { participate in learning object study }\end{array}$ \\
\hline & August 2004 & $\begin{array}{l}\text { Preservice Teachers were given opportunity } \\
\text { to participate in the study }\end{array}$ \\
\hline Mock Prototyping & Sept 2004 (2 hours) & $\begin{array}{l}\text { Subject team introduced to learning objects } \\
\text { by creating paper-based prototype }\end{array}$ \\
\hline Role Assignment & Sept 2004 (1 hour) & $\begin{array}{l}\text { Each team completed profiles to determine } \\
\text { role of each member }\end{array}$ \\
\hline Project Planning & Nov 2004 (half day) & $\begin{array}{l}\text { Subject teams brainstormed topics, selected } \\
\text { topic for learning object, a listed goals }\end{array}$ \\
\hline Understanding Learners & Nov 2004 (half day) & $\begin{array}{l}\text { Formal presentation on key qualities of } \\
\text { learning objects and analysis of learners } \\
\text { completed }\end{array}$ \\
\hline Prototyping and Usability & Nov 2004 (1.5 days) & $\begin{array}{l}\text { Subject teams produced detailed paper and } \\
\text { pencil prototype of their learning objects }\end{array}$ \\
\hline Electronic Prototype & Dec 2004 & $\begin{array}{l}\text { One team member creates PowerPoint } \\
\text { prototype of learning object }\end{array}$ \\
\hline $\begin{array}{l}\text { Programming Learning } \\
\text { Object }\end{array}$ & Jan 2005 & $\begin{array}{l}\text { One team member programs Flash version } \\
\text { of learning object with multimedia expert }\end{array}$ \\
\hline Team Formative Evaluation & Feb 2005 (half day) & $\begin{array}{l}\text { Subject teams evaluate each other's Flash } \\
\text { versions of learning objects }\end{array}$ \\
\hline Pilot Test & Feb 2005 (1 day) & $\begin{array}{l}\text { Learning objects tested on } 40 \text { volunteer } \\
\text { students }\end{array}$ \\
\hline $\begin{array}{l}\text { External Formative } \\
\text { Evaluation }\end{array}$ & Feb 2005 (half day) & $\begin{array}{l}\text { CLOE expert provides feedback on learning } \\
\text { objects }\end{array}$ \\
\hline Revision Plan & Feb 2005 (half day) & $\begin{array}{l}\text { Subject teams digest student and expert } \\
\text { feedback and make plan for further } \\
\text { revisions }\end{array}$ \\
\hline Final Revisions & March 2005 & $\begin{array}{l}\text { Flash multimedia programmer modifies all } \\
5 \text { learning objects based on revision plans }\end{array}$ \\
\hline Implementation & March - Apr 2005 & $\begin{array}{l}\text { Five learning objects are implemented and } \\
\text { evaluated by students }\end{array}$ \\
\hline Teacher Evaluation & April 2005 & $\begin{array}{l}\text { Subject teams brought together to evaluate } \\
\text { implementation of learning objects future } \\
\text { revisions }\end{array}$ \\
\hline
\end{tabular}




\section{Selection of learning objects participants (March)}

Six months prior to the start of the project, experienced secondary school teachers were recruited from local school boards in the Toronto area via email and phone. Nine certified, secondary school teachers (10 to 25 years experience), representing the five key subject areas (biology, physics, chemistry, computer science and mathematics) offered at UOIT's Faculty of Education, volunteered to be part of the project.

A month prior to the start of the project, teacher candidates were given the opportunity to be part of the research study. The researcher interviewed applicants and selected 21 teacher candidates.

The criterion for selection was based on a student's ability to handle the extra workload involved. These candidates were training to teach in one of the five subject areas which would form the learning object groups. Team sizes ranged from five to eight members.

\section{Mock prototyping (2 hours - September workshop)}

The subject matter teams were given various case scenarios and required to create a paper-based, mock design of what the first few screens of a learning object might look like. After one hour, several members of each team systematically circulated around the room to view the prototypes. Each team left behind a few members to demonstrate their mock learning object and obtain feedback. This first step in the CLOE model helps team members to (a) experience the first stages of learning object design, (b) develop an understanding of each other's strengths and potential contributions to the group, and (c) see the benefits of the feedback process.

\section{Role assignment (1 hour - September workshop)}

Each subject team was asked to complete a group profile sheet to identify the various strengths of team members. This profile sheet showed what skills were present in the group in terms of subject matter expertise, instructional design abilities, Flash experience, programming, and leadership experience. The team then assigned roles to each member based on the profile feedback (e.g., subject matter expert, flash programmer, graphical designer, group co-ordinator, content writer)

\section{Project planning (half day -November workshop)}

The subject groups brainstormed the possible topics for their learning object. The experienced teachers guided the discussion toward topics students struggled with at the secondary school level. After choosing a topic, team members created a summary of the goals and objectives. The entire group was warned of 'scope creep' where ambitious ideas "creep" toward being too complex to complete within the eight month time frame allotted. Next, teams were asked to describe how their subject areas was currently taught and where the learning object fit in with regards to the course of study and teaching strategies. The experienced teachers lead and guided this part of the discussion. Finally, the team had to clearly outline the specific tasks, duties and milestones to be reached over the next five months. A calendar was provided so team members could start assigning deadline dates and tasks for group members. Teams were to have a completed a paperprototype by mid-December, a digital prototype (using PowerPoint) by mid-January, and a complete Flash version of the learning object to be pilot-tested in February.

\section{Understanding learners (half day - November workshop)}

The LT3 faculty member and researcher gave a formal presentation on the key characteristics that make a learning object beneficial. The researcher then showcased two exemplary learning objects to provide teams with a concrete idea of typical layouts, organization, graphics, and key functions. 
Subject teams were then asked to complete a task sheet to consider how their secondary school students would learn the topic they had proposed for the learning object. This was step was done so that teams could identify sound learning strategies to use within the learning object.

The final component for "understanding the learners" was a presentation and work period to prepare a persona. A persona is a hypothetical archetype of actual users including age, grade, gender, interests, reason for using learning object, etc. This persona exercise was to help the team members hone in on what motivated the intended audience.

\section{Prototyping and usability testing (1.5 days - November workshop)}

First, the subjects teams were asked to produce a "low fidelity" paper prototype of their learning object. This task involved a rather quick articulation of the components of their learning object on paper. Debriefing of the process and sharing of their work with other subject teams also occurred.

Next, the subject teams were asked to create detailed, screen-by-screen paper prototypes (medium fidelity) of their learning objects. Each screen had to include complete text, description of buttons, navigational elements and graphics. If a button indicated movement to another page, another piece of paper was produced with that screen's content.

Paper prototyping works particularly well if regular feedback is worked into the process (Nielson, 1994). Every two hours subject teams were asked to circulate around the room, and give feedback on other group's learning object designs. The feedback was digested by the designers and actively incorporated by teams into a next version of the prototype. It was not uncommon for 10-20 versions of the paper-prototype to emerge over the span of this one and a half day workshop.

The primary product at the end of the "Prototyping and Usability Testing" session was to have a medium fidelity paper prototype complete with descriptions of each button, page, and activity within the prototype. This final paper prototype was given to the team member who was assigned to work on the electronic prototype.

\section{Electronic prototyping (one month - December)}

Microsoft PowerPoint was used to transform the paper prototype into a semi-working electronic version of the learning object. Over the course of a month, one team member took on the responsibility of completing the electronic prototype which included interactivity with buttons, sounds and graphics. Throughout this process, feedback was solicited from other team members. Edits and modifications were made through an online discussion board where various versions of the prototype were posted and comments from team members were discussed. All electronic prototypes were done by early to mid-January and shared with the researcher and other designers.

\section{Programming (one month - January)}

A Flash programmer/ multimedia designer sat down with each group and observed their electronic prototype. He discussed what challenges they would have and different strategies for getting started in Flash. He also worked with some groups on file structures and programming basics. Additionally, key Flash tutorials and websites were made available to students for getting started in working with Flash. Most of the Flash work was done independently by the teacher candidates.

After consultation with the Flash programmer, one or more team members (depending on assigned team roles) worked on transforming the PowerPoint digital prototype into a Macromedia Flash learning object. This stage was the most demanding as no one in the subject teams had ever used Flash. The Flash developer was made available to them from January to March when they were on campus. Some students took advantage of individual learning sessions to acquire the ex- 
pertise in manipulating Flash components and nuances. All Flash learning objects were turned into the Flash programmer a week before the pilot study in late February. The programmer fixed bugs and critical interface problems.

\section{Formative evaluation of Macromedia Flash learning object (half day- February)}

The subject teams then met again to present the first Flash versions of their learning objects. Each team had approximately 15 minutes to go through their learning object, describe interactivity components, and highlight sections that each member had done. The entire learning object group provided feedback during and after each presentation.

\section{Pilot testing (1 day - February)}

Forty secondary school students from a single high school volunteered to pilot test the learning objects. Prior to arriving at the school, the subject teams were coached on how to approach the testing process. This involved writing a common script, understanding the evaluation tool produced by the researcher, and practising how they would set up and have students work with the learning object. Secondary school students from specific subject areas engaged with the learning objects for approximately 45 minutes and then completed a 15 minute survey. Subject teams debriefed afterwards to consolidate the feedback given.

\section{External formative evaluation (half day - February)}

The following day, the CLOE Director from the University of Waterloo visited and provided oneto-one guidance and feedback for improving the learning objects. The CLOE Director had expertise in review and assessment of learning objects and provided on-the-spot advice to each team during their pre-arranged meeting.

\section{Revision discussions (half day - February)}

Subject teams returned to the afternoon session with a strong sense of modifications needed. Both the secondary school students and the CLOE expert had given them a number of key areas for improvement. The team spent the rest of session making plans for revisions, rewording components, and reorganizing the screen layout. Helpful guides or cartoon characters were devised, help menus arose, and assessment ideas were incorporated. The researcher then met with teacher candidates from each subject team to discuss and review plans for revising learning objects.

\section{Final revisions for learning object (one month- March)}

The Flash developer was assigned to revise all five learning objects. He incorporated changes from the expert and student testing. By the beginning of April, all learning objects were uploaded to the UOIT website (see http://education.uoit.ca/learningobjects).

\section{Implementation (5 weeks - March to April)}

Consent forms and letters of invitation were mailed out to the 30 participants (both teachers and teacher candidates) in the study. Consent forms had to be completed by both students and parents before the learning object was administered.

Teachers and teacher candidates were instructed to use the learning object as authentically as possible. Since the evaluation period was confined to specific five week period in the middle of the term, sometimes the subject matter of the learning object had been taught, so it was used as a review tool. Sometimes the subject matter had yet to be taught and therefore the learning object was used as an introduction to the topic. 
Students were taken to a computer lab with Internet access, given some preliminary introduction to the learning object, and then asked to use it. Teachers provided input and assistance to individual students as needed. After one period of using the learning object (approximately 70 minutes), students were asked to fill out a survey (see Appendix A).

\section{Debriefing (half day - late April)}

Teachers and teacher candidates filled out a survey (Appendix B). They also gathered in their teams and completed charts on the process of implementing the learning object. In addition, they also completed a list of items they felt were necessary for further revision and editing of their learning objects.

\section{Guiding Design Principles}

\section{Technical}

Two key technical features were addressed in the development of the learning objects in this study - reusability and accessibility. The guidance and perspective of experienced subject matter teachers was used to create meaningful objects that could exist in a larger context. Polsani (2003) identifies this "conceptualization" as critical to developing reusable products. In addition, a specific concept was chosen for each of the five learning objects created, allowing for multiple uses at different grade levels. With respect to accessibility, a Flash format was used create the final web-based, versions of the learning objects. This is a format that is readily and quickly accessible to all schools in Ontario and most Internet users. The Sharable Courseware Object Reference Model (SCORM) standards were not strictly adhered to because of (a) the reported inflexibility of this model to allow for a variety of pedagogies (Downes, 2003) and (b) the potential complexities of the standards slowing down other aspects of the development process.

\section{Learning}

The learning objects were designed at the grassroots level by preservice and experienced teachers. Wiley (2000) maintained that learning objects need to be sufficiently challenging, so experienced teachers were asked to brainstorm about and select areas where their students had the most difficulty. Second, the learning objects were designed to be content-rich, however they focussed on a relatively specific topic areas that could be shared by different grades. Reusability, while important, took a back seat to developing meaningful and motivating problems. This approach is supported by a number of learning theorists (Brown, Collins \& Duguid, 1989; Lampert, 1986; Larkin, 1989; Lave \& Wenger, 1991; Sternberg, 1989). Third, the learning objects were both interactive and constructivist in nature. Students interacted with the computer, but not simply by clicking "next, next, next." They had to construct solutions to genuine problems. Finally, the "octopus" or resource model proposed by Wiley et al., (2004) was used. The learning objects were designed to support and reinforce understanding of specific concepts. They were not designed as stand alone modules that could teach concepts.

\section{Description of the Learning Objects}

All learning objects can be accessed at: http://education.uoit.ca/learningobjects. A brief description is provided below.

\section{Mathematics}

This learning object (Deep Space Line) was designed to help grade 9 students explore the formula and calculations for the slope of a line. Students used their knowledge of slope to navigate a 
spacecraft through four missions. As the missions progressed from level one to level four, less scaffolding was provided to solve the mathematical challenges.

\section{Physics}

This learning object (Relative Velocity) helped grade 11 and 12 students explore the concept of relative velocity. Students completed two case study questions, and then actively manipulated the speed and direction of a boat, along with the river speed, to see how these variables affect relative velocity.

\section{Biology}

This learning object (Goovy Genetics) was designed to help grade 11 students investigate the basics of Mendel's genetics relating the genotype (genetic trait) with the phenotype (physical traits) including monohybrid and dihybrid crosses. Students had a visual instruction to complete Punnett squares. Each activity finished with an assessment.

\section{Chemistry}

This grade12-oriented learning object (Le Chatelier's Principle) demonstrated the three stresses (concentration, temperature $\&$ pressure change) that can be imposed to a system at chemical equilibrium. Students explored how equilibrium shifts related to Le Chatelier's Principle. Students assessed their learning in a simulated laboratory environment by imposing changes to equilibrated systems and predicting the correct outcome.

\section{Computer Science}

This learning object (Logic Flows) was designed to teach grade 10 or 11 students the six basic logic operations (gates) AND, OR, NOT, XOR (exclusive OR), NOR (NOT-OR) and NAND (NOT-AND) through a visual metaphor of water flowing through pipes. Students selected the least number of inputs (water taps) needed to get a result in the single output (water holding tank) to learn the logical function of each operation.

\section{Sample}

\section{Students}

The sample consisted of a 221 secondary school students (104 males, 116 females, 1 missing data), 13 to 17 years of age, in grades $9(n=85), 11(n=67)$, and $12(n=69)$ from twelve different high schools and three boards of education. The students were obtained through convenience sampling.

\section{Teachers}

A total of 30 teachers ( 9 experienced, 21 preservice) participated in the development of the learning objects. The breakdown by subject area was eight for Biology (two experienced, six preservice), five for Chemistry (two experienced, three preservice), five for Computer Science (one experienced, four preservice), five for Physics (one experienced, four preservice), and seven for Math (three experienced, four preservice).

\section{Learning objects}

Five learning objects in five different subject areas were evaluated by secondary school students. Seventy-eight students used the Mathematics learning object (grade 9), 40 used the Physics learning object (grades 11 and 12), 37 used the Chemistry learning object (grade 12), 34 used the Bi- 
ology learning object (grades 9 and 11), and 32 used the Computer Science learning object (grades 11 and 12).

\section{Data Sources}

\section{Students - perceived benefit of learning object}

The data for this study was gathered using four items based on a 7-point Likert scale, and two open ended questions (see Appendix A). Items one to four examined perceived student benefit and had an internal reliability rating of .87. Item 5 (Appendix A) was an open ended question asking students whether the learning object was beneficial. Two-hundred and twenty five comments were made and categorized according to nine post-hoc categories (Table 2). Each comment was then rated on a five-point Likert scale $(-2=$ very negative, $-1=$ negative, $0=$ neutral, $1=$ positive, $2=$ very positive).

Table 2: Coding Scheme for Assessing Learning Object Benefits (Item 5 - Appendix A)

\begin{tabular}{|c|c|c|}
\hline Reason Category & Criteria & Sample Student Comments \\
\hline 1. Timing & $\begin{array}{l}\text { When the learning object was } \\
\text { introduced in the curriculum }\end{array}$ & $\begin{array}{l}\text { "I think I would have benefited more if } \\
\text { I used this program while studying the } \\
\text { unit." } \\
\text { "It didn't benefit me because that par- } \\
\text { ticular unit was over. It would have } \\
\text { helped better when I was first learning } \\
\text { the concepts." }\end{array}$ \\
\hline $\begin{array}{l}\text { 2. Review of Basics / } \\
\text { Reinforcement }\end{array}$ & $\begin{array}{l}\text { Refers to reviewing, reinforcing } \\
\text { concept, practice. }\end{array}$ & $\begin{array}{l}\text { "going over it more times is always } \\
\text { good for memory" } \\
\text { "it did help me to review the concept } \\
\text { and gave me practise in finding the } \\
\text { equation of a line." }\end{array}$ \\
\hline $\begin{array}{l}\text { 3. Interactive / Hands } \\
\text { On / Learner Con- } \\
\text { trol }\end{array}$ & $\begin{array}{l}\text { Refers to interactive nature of the } \\
\text { process }\end{array}$ & $\begin{array}{l}\text { "I believe I did, cause I got to do my } \\
\text { own pace ... I prefer more hands on } \\
\text { things (like experiments)." } \\
\text { "Yes, it helped because it was interac- } \\
\text { tive." }\end{array}$ \\
\hline $\begin{array}{l}\text { 4. Good for visual } \\
\text { learners }\end{array}$ & $\begin{array}{l}\text { Refers to some visual aspect of } \\
\text { the process }\end{array}$ & $\begin{array}{l}\text { "I was able to picture how logic gates } \\
\text { function better through using the learn- } \\
\text { ing object." } \\
\text { "I found it interesting. I need to see it" }\end{array}$ \\
\hline 5. Computer Based & $\begin{array}{l}\text { Refers more generally to liking to } \\
\text { work with computers }\end{array}$ & $\begin{array}{l}\text { "I think that digital learning kind of } \\
\text { made the game confusing." } \\
\text { "I think I somewhat did because I find } \\
\text { working on the computer is easier then } \\
\text { working on paper. " }\end{array}$ \\
\hline 6. Fun / Interesting & $\begin{array}{l}\text { Refers to process being fun, in- } \\
\text { teresting, motivating }\end{array}$ & $\begin{array}{l}\text { "I think I learned the concepts better } \\
\text { because it made them more interesting." } \\
\text { "I think I did. The learning object } \\
\text { grasped my attention better than a } \\
\text { teacher talking non-stop." }\end{array}$ \\
\hline 7. Learning Related & $\begin{array}{l}\text { Refers to some aspect of the } \\
\text { learning process }\end{array}$ & $\begin{array}{l}\text { "I don't think I learned the concept bet- } \\
\text { ter." } \\
\text { "It did help me teach the concept better" }\end{array}$ \\
\hline
\end{tabular}




\begin{tabular}{|c|c|c|c|}
\hline & Clarity & $\begin{array}{l}\text { Refers to the clarity of the pro- } \\
\text { gram and/or the quality of in- } \\
\text { struction }\end{array}$ & $\begin{array}{l}\text { "I think it was very confusing and hard } \\
\text { to understand." } \\
\text { "Yes, this helped me. It made it much } \\
\text { clearer and was very educational." }\end{array}$ \\
\hline & $\begin{array}{l}\text { Not good at sub- } \\
\text { ject }\end{array}$ & $\begin{array}{l}\text { Refers to personal difficulties in } \\
\text { subject areas }\end{array}$ & $\begin{array}{l}\text { "No, to be honest it bothered me. In } \\
\text { general I don't enjoy math and this did } \\
\text { not help." }\end{array}$ \\
\hline & $\begin{array}{l}\text { Compare to other } \\
\text { method }\end{array}$ & $\begin{array}{l}\text { Compared to other teaching } \\
\text { method / strategy }\end{array}$ & $\begin{array}{l}\text { "Yes, because it... is better than having } \\
\text { the teacher tell you what to do." } \\
\text { "Would rather learn from a book." }\end{array}$ \\
\hline & No reason given & & $\begin{array}{l}\text { "I didn't benefit from any of it." } \\
\text { "Yes." }\end{array}$ \\
\hline
\end{tabular}

Criterion related validity for perceived benefit score was assessed by correlating the survey score (Items 1 to 4 ) with the qualitative ratings (Item 5). The correlation was significant (.64; $p<.001)$.

\section{Students - quality of learning object}

Item 6 (Appendix A) asked students what they liked and did not like about the learning object. A total of 757 comments were written down by 221 students. Student comments were coded based on well-established principles of instructional design. Thirteen categories are presented with examples and references in Table 3 . In addition, all comments were rated on a five-point Likert scale $(-2=$ very negative, $-1=$ negative, $0=$ neutral, $1=$ positive, $2=$ very positive $)$.

Two raters assessed the first 100 comments made by students and achieved inter-rater reliability of .78. They then met, discussed all discrepancies and attained $100 \%$ agreement. Next the raters assessed the remaining 657 comments with an inter-rated reliability of .66. All discrepancies were reviewed and $100 \%$ agreement was reached again.

Table 3: Coding Scheme for Assessing Learning Object Quality (Item 6 - Appendix A)

\begin{tabular}{|c|c|c|}
\hline Category \& References & Criteria & Sample Student Comments \\
\hline $\begin{array}{ll}\text { 1. } & \text { Organization / Layout } \\
\text { (Calvi, 1997; Koehler \& Lehrer, } \\
\text { 1998; Lorch, 1989; Madhumita \& } \\
\text { Kumar, 1995) }\end{array}$ & $\begin{array}{l}\text { Refers to the location } \\
\text { or overall layout of } \\
\text { items on the screen }\end{array}$ & $\begin{array}{l}\text { "Sometimes we didn't know where/what } \\
\text { to click." } \\
\text { "I found that they were missing the next } \\
\text { button." } \\
\text { "Easy to see layout" } \\
\text { "[Use a] full screen as opposed to small } \\
\text { box." }\end{array}$ \\
\hline 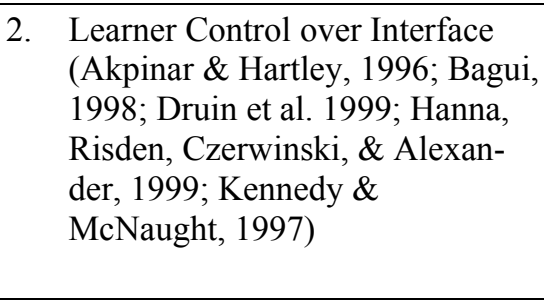 & $\begin{array}{l}\text { Refers the control of } \\
\text { the user over specific } \\
\text { features of the learning } \\
\text { object including pace } \\
\text { of learning }\end{array}$ & $\begin{array}{l}\text { "[I liked] that it was step by step and I } \\
\text { could go at my own pace." } \\
\text { "I liked being able to increase and de- } \\
\text { crease volume, temperature and pres- } \\
\text { sure on my own. It made it easier to } \\
\text { learn and understand." } \\
\text { "It was too brief and it went too fast." }\end{array}$ \\
\hline $\begin{array}{ll}\text { 3. } & \text { Animation } \\
\text { (Gadanidis et al., 2003; Oren, } \\
\text { 1990; Stoney \& Wild, 1998; } \\
\text { Sedig \& Liang, 2006) }\end{array}$ & $\begin{array}{l}\text { Refers specifically to } \\
\text { animation features of } \\
\text { the program }\end{array}$ & $\begin{array}{l}\text { "You don't need all the animation. It's } \\
\text { good to give something good to look at, } \\
\text { but sometimes it can hinder progress." } \\
\text { "I liked" the fun animations" } \\
\text { "Like how it was linked with little mov- } \\
\text { ies ... demonstrating techniques." } \\
\text { "I liked the moving spaceship. }\end{array}$ \\
\hline
\end{tabular}




\begin{tabular}{|c|c|c|}
\hline $\begin{array}{l}\text { 4. Graphics } \\
\text { (Gadanidis et al., 2003; Oren, } \\
\text { 1990; Stoney \& Wild, 1998; } \\
\text { Sedig \& Liang, 2006) }\end{array}$ & $\begin{array}{l}\text { Refers to graphics (non } \\
\text { animated of the pro- } \\
\text { gram), colours, size of } \\
\text { text }\end{array}$ & $\begin{array}{l}\text { "The pictures were immature for the } \\
\text { age group." } \\
\text { "I would correct several mistakes in the } \\
\text { graphics" } \\
\text { "The graphics and captions that ex- } \\
\text { plained the steps were helpful." } \\
\text { "Change the colours to be brighter." }\end{array}$ \\
\hline $\begin{array}{l}\text { 5. Audio } \\
\text { (Gadanidis et al., 2003; Oren, } \\
\text { 1990; Stoney \& Wild, 1998; } \\
\text { Sedig \& Liang, 2006) }\end{array}$ & $\begin{array}{l}\text { Refers to audio fea- } \\
\text { tures }\end{array}$ & $\begin{array}{l}\text { "Needed a voice to tell you what to do" } \\
\text { "Needs sound effects" } \\
\text { "Unable to hear the character (no sound } \\
\text { card on computers)." }\end{array}$ \\
\hline $\begin{array}{ll}6 . & \text { Clear Instructions } \\
\text { (Acovelli \& Gamble, 1997; } \\
\text { Jones, Farquhar, \& Surry 1995; } \\
\text { Kennedy \& McNaught, 1997; } \\
\text { MacDonald et al., 2005) }\end{array}$ & $\begin{array}{l}\text { Refers to clarity of } \\
\text { instructions before } \\
\text { feedback or help is } \\
\text { given to the user }\end{array}$ & $\begin{array}{l}\text { "Some of the instruction were confus- } \\
\text { ing" } \\
\text { "I ... found it helpful running it through } \\
\text { first and showing you how to do it." } \\
\text { "[I needed] ... more explana- } \\
\text { tions/Clearer instructions. }\end{array}$ \\
\hline $\begin{array}{l}\text { 7. Help Features } \\
\text { (Acovelli \& Gamble, 1997; Jones } \\
\text { et al., 1995; Kennedy \& } \\
\text { McNaught, 1997; MacDonald et } \\
\text { al., 2005) }\end{array}$ & $\begin{array}{l}\text { Refers to help features } \\
\text { of the program }\end{array}$ & $\begin{array}{l}\text { "The glossary was helpful." } \\
\text { "Help function was really good" } \\
\text { "Wasn't very good in helping you when } \\
\text { you were having trouble...I got more } \\
\text { help from the teacher than it." }\end{array}$ \\
\hline $\begin{array}{l}\text { 8. Interactivity } \\
\text { (Akpinar \& Hartley, 1996; Bagui, } \\
\text { 1998; Druin et al. 1999; Hanna et } \\
\text { al., 1999; Kennedy \& McNaught, } \\
\text { 1997) }\end{array}$ & $\begin{array}{l}\text { Refers to general inter- } \\
\text { active nature of the } \\
\text { program }\end{array}$ & $\begin{array}{l}\text { "Using the computer helped me more } \\
\text { for genetics because it was interactive." } \\
\text { "I like that it is on the computer and you } \\
\text { were able to type the answers." } \\
\text { "I liked the interacting problems" }\end{array}$ \\
\hline 9. Incorrect Content / Errors & $\begin{array}{l}\text { Refers to incorrect } \\
\text { content }\end{array}$ & $\begin{array}{l}\text { "There were a few errors on the sight." } \\
\text { "In the dihybrid cross section, it showed } \\
\text { some blond girls who should have been } \\
\text { brunette." }\end{array}$ \\
\hline $\begin{array}{l}\text { 10. Difficulty / Challenge Levels } \\
\text { (Hanna et al., 1999; Klawe, 1999; } \\
\text { Savery \& Duffy, 1995) }\end{array}$ & $\begin{array}{l}\text { Was the program chal- } \\
\text { lenging? Too easy? } \\
\text { Just the right difficulty } \\
\text { level? }\end{array}$ & $\begin{array}{l}\text { "Make it a bit more basic." } \\
\text { "For someone who didn't know what } \\
\text { they were doing, the first few didn't } \\
\text { teach you anything but to drag and } \\
\text { drop." } \\
\text { "I didn't like how the last mission was } \\
\text { too hard." }\end{array}$ \\
\hline $\begin{array}{l}\text { 11. Useful / Informative } \\
\text { (Sedig \& Liang, 2006) }\end{array}$ & $\begin{array}{l}\text { Refers to how useful } \\
\text { or informative the } \\
\text { learning object was }\end{array}$ & $\begin{array}{l}\text { "I like how it helped me learn" } \\
\text { "I found the simulations to be very use- } \\
\text { ful" } \\
\text { "[The object] has excellent review ma- } \\
\text { terial and interesting activities." } \\
\text { "I don't think I learned anything from it } \\
\text { though." }\end{array}$ \\
\hline $\begin{array}{ll}\text { 12. } & \text { Assessment } \\
\text { (Atkins, 1993; Kramarski \& } \\
\text { Zeichner, 2001; Sedighian, 1998; } \\
\text { Wiest, 2001; Zammit, 2000) }\end{array}$ & $\begin{array}{l}\text { Refers to summative } \\
\text { feedback/ evaluation } \\
\text { given after a major } \\
\text { task (as opposed to a } \\
\text { single action) is com- } \\
\text { pleted }\end{array}$ & $\begin{array}{l}\text { No specific comments offered by stu- } \\
\text { dents }\end{array}$ \\
\hline
\end{tabular}




\begin{tabular}{|l|l|l|}
\hline $\begin{array}{l}\text { 13. Theme / Motivation } \\
\text { (Akpibar \& Hartley, 1996; Harp } \\
\text { \& Mayer, 1998) }\end{array}$ & $\begin{array}{l}\text { Refers to overall theme } \\
\text { and /or motivating } \\
\text { aspects of the learning } \\
\text { object }\end{array}$ & $\begin{array}{l}\text { "Very boring. Confusing. Frustrating." } \\
\text { "Better than paper or lecture - game is } \\
\text { good!" } \\
\text { "I liked it because I enjoy using com- } \\
\text { puters, and I learn better on them." }\end{array}$ \\
\hline
\end{tabular}

\section{Teachers - perceived benefit of learning object}

Because teachers, who helped create the learning objects, also administered it to their classes for testing, there may be a bias towards evaluating the learning objects more positively. Therefore, teacher feedback was used to corroborate what students reported. A survey consisting of five Likert and two open-ended questions was given to experienced and preservice teachers after students had used the learning objects. The focus of these questions was to assess the benefits of learning objects to students. (Appendix B). The number of teachers who filled in this survey is relatively small $(n=26)$, so internal reliability estimates are not reported.

\section{Teachers - quality of learning object}

Data from a half-day focus group was collected to evaluate the quality of the learning object and suggestions for improvements.

\section{Results}

\section{Perceived Benefit of Learning Object - Students}

Based on the average perceived benefit rating from the survey (items 1 to 4 - Appendix A), it appears the students felt the learning object was more beneficial than not $(M=4.8, S D=1.5$; scale ranged from 1 to 7). Fourteen percent of all students $(n=30)$ disagreed (average score of 3 or less) that the learning object was of benefit whereas $55 \%(n=122)$ agreed (average score of 5 or more) that it was useful.

The qualitative comments (Q9 - Appendix A) supported the survey results. Sixty-six percent ( $\mathrm{n}=$ 146) of the students felt that the learning objects were beneficial.

A more detailed examination indicated that the motivational, interactive, and visual qualities were most important to students who benefited from the learning object. Whether they learned something new was also cited frequently and rated highly. Presenting the learning object after the topic had already been learned and poor instructions were the top two reasons given by students who did not benefit from the learning object (Table 4).

Table 4: Mean Ratings for Reasons Given for Benefits of Learning Objects (Q9)

\begin{tabular}{lrrr}
\hline Reason & $\mathrm{n}$ & Mean & Std. Deviation \\
\hline Fun / Interesting & 17 & 1.35 & 0.74 \\
Visual Learners & 33 & 1.24 & 0.84 \\
Interactive & 30 & 1.17 & 1.34 \\
Learning Related & 37 & 0.81 & 1.13 \\
Good Review & 60 & 0.80 & 1.04 \\
Computer Based & 5 & 0.20 & 1.40 \\
Compare to Another Method & 24 & 0.00 & 1.18 \\
Timing & 21 & -0.29 & 1.19 \\
Clarity & 33 & -0.55 & 0.00 \\
Not good at subject & 3 & -1.35 & 0.38 \\
\hline
\end{tabular}




\section{Perceived Benefit of Learning Object - Teacher}

Overall, experienced and preservice teachers strongly agreed that the learning object was a beneficial learning strategy for students (Item $1-M=6.5, S . D .=0.6$ ) and were interested in using the learning object in their classrooms again (Item $3-M=6.6, S . D .=0.6$ ). The teachers moderately agreed that the learning object helped students with respect to understanding concepts $(M=5.4$, $S . D .=1.2)$ and that students would want to use the learning object again $(M=5.5, S . D .=1.7)$. Teachers agreed that the learning objects would have been more successful if they had been implemented at the right time in the curriculum $(M=6.0, S . D .=1.4)$. Recall, that the learning objects were used during the field experience placements and may not have been introduced at a pedagogically appropriate time. Finally, there were non significant differences between experienced and preservice teachers with respect to the perceived benefits (Items 1 to 4 ) of the learning objects (Hotelling's $\mathrm{T}^{2}-$ n.s.).

In the open-ended questions (Appendix B - Items 6 and 7), teachers reported that that students liked the visual or graphics qualities so the learning objects best $(n=15 ; 58 \%)$ followed by the interactivity $(\mathrm{n}=12 ; 46 \%)$ and motivating theme $(\mathrm{n}=7 ; 27 \%)$. With respect to dislikes, teachers noted that some students had difficulty following the instructions $(n=5 ; 19 \%)$, found the theme boring $(n=5 ; 19 \%)$ or were distracted by some of the computer bugs found $(n=4 ; 15 \%)$.

\section{Quality of Learning Object - Students}

\section{Overview}

Students were relatively negative with respect to their comments about learning object quality (Item 6 - Appendix A). Fifty-seven percent of all comments were either very negative $(n=42$, $6 \%)$ or negative $(n=392,52 \%)$ whereas only $42 \%$ of the students made positive $(n=258,34 \%)$ or very positive $(\mathrm{n}=57,8 \%)$ statements about learning object quality.

\section{Categories}

An analysis of categories evaluating learning object quality (see Table 3 for description) identified animation, interactivity, and usefulness as the highest rated areas and audio, correct information, difficulty, clarity of instructions, and help functions as the lowest rated. Table 5 provides means and standard deviation for all categories assessing the quality of learning objects.

Table 5: Mean Ratings for Categories Evaluating Learning Object Quality

\begin{tabular}{llll}
\hline Category & $\mathrm{n}$ & Mean & Std. Deviation \\
\hline Animations & 27 & 0.81 & 0.74 \\
Interactivity & 47 & 0.66 & 0.84 \\
Useful & 39 & 0.51 & 1.34 \\
Assessment & 9 & 0.44 & 1.13 \\
Graphics & 84 & 0.25 & 1.04 \\
Theme/ Motivation & 125 & 0.12 & 1.40 \\
Organization & 34 & -0.06 & 1.18 \\
Learner Control & 75 & -0.12 & 1.19 \\
Help Functions & 42 & -0.43 & 1.02 \\
Clear Instructions & 138 & -0.61 & 0.95 \\
Difficulty & 107 & -0.67 & 0.81 \\
Information Correct & 17 & -1.00 & 0.00 \\
Audio & 13 & -1.15 & 0.38 \\
\hline
\end{tabular}


A one-way ANOVA comparing categories of learning object quality was significant $(p<.001)$. Audio, correct information, and difficulty were rated significantly lower than animations, interactivity, and usefulness (Scheffé post hoc analysis, $p<.05$ ).

\section{Categories - likes only}

One might assume that categories with mean ratings close to zero are not particularly important with respect to evaluation. However, it is possible that a mean of zero could indicate an even split between students who liked and disliked a specific category. Therefore, it is worth looking at what students liked about the learning objects, without dislikes, to identify polar "hot spots." A comparison of means for positive comments confirmed that usefulness $(M=1.33)$ was still important, but that theme and motivation $(M=1.35)$, learner control $(M=1.35)$, and organization of the layout $(M=1.20)$ also received high ratings. These areas had mean ratings that were close to zero when negative comments were included (see Table 5). This indicates than students had relatively polar attitudes about these categories.

\section{Categories - dislikes only}

A comparison of means for negative comments indicated that usefulness ( $M=-1.33)$ remained important, however theme and motivation $(M=-1.32)$ was also perceived as particularly negative. Students appeared to either like or dislike the theme or motivating qualities of the learning object.

\section{Correlation between learning object quality and perceived benefit}

Theme and motivation $(r=.45 ; p<.01)$, the organization of the layout $(r=.33 ; p<.01)$, clear instructions $(r=.33 ; p<.01)$, and usefulness $(r=.33 ; p<.01)$ were significantly correlated with the perceived benefit score measured by the survey (items 1 to 4 - Appendix A).

\section{Quality of Learning Object - Teachers}

With respect to the positive qualities of learning objects, two key themes emerged in the focus groups for all five learning objects: graphics and interactivity. These were to two most salient qualities that students liked best. Regarding areas for improvement, feedback varied according to the specific learning object used. The Biology group reported that students wanted better audio and more challenges. The Chemistry group noted that teacher support was necessary for the learning objects and that some instructions were unclear. The Computer Science group noted that students liked the learning object but wanted more difficult circuits. The Math group felt the success of the learning object was tied closely to when the concept was taught and in what format (group vs. individual). Finally, the Physics group noted a number of bugs slowed students down, as well as some obscure instructions.

The focus groups also reported a series of programming changes that would help improve the consistency and quality of the learning objects (see Table 6). 
Table 6: Proposed Programming Changes for Learning by Subject Area

\begin{tabular}{|c|c|}
\hline $\begin{array}{l}\text { Learning } \\
\text { Object }\end{array}$ & Proposed Changes \\
\hline Biology & $\begin{array}{l}\text { - Integrate dihybrid activity. } \\
\text { - In dihybrid Punnett square \#1: } \\
\circ \quad \text { Blue squares updated to question marks. } \\
\circ \text { Prompt for next button removed. } \\
\text { - In dihybrid analysis \#1: } \\
\circ \quad \text { Click and drag too repetitive. } \\
\text { - Eye colour difficult to see in dihybrid section. } \\
\text { - Fix credits } \\
\text { - Monohybrid - "What is monohybrid" tab: } \\
\circ \quad \text { Remove word "dominant" from heterozygous. } \\
\text { - Monohybrid Punnett \#1: } \\
\circ \text { "The off spring..." - Should be on one line. } \\
\text { - Dihybrid Punnett \#1: } \\
\circ \quad \text { Words in combination box on one line. }\end{array}$ \\
\hline Chemistry & $\begin{array}{l}\text { - } \quad \text { Give example of catalyst/noble gas in year } 3 . \\
\text { - } \quad \text { Correct" change text colour to green or blue. } \\
\text { - } \quad \text { Update credits. } \\
\text { - } \quad \text { Link to activities in each year. } \\
\text { - } \quad \text { Simulation. } \\
\text { - } \quad \text { Remove title from certificate frame. } \\
\text { - } \quad \text { Size of screen - too small }\end{array}$ \\
\hline Math & $\begin{array}{l}\text { - Make help more obvious (Have a bubble? Bubbles for areas of the screen (con- } \\
\text { sole and intro to the screen). } \\
\text { - Press "Enter" on the keyboard instead of "next" on screen (when prompted for } \\
\text { text). } \\
\text { - Mission } 2 \text { - Students didn't know that they needed to do the calculations on their } \\
\text { own using pencil and paper. Instructions need to be more explicit. } \\
\text { - "Instruction" font size and colour are too small and too dark. } \\
\text { - Options to go back to other missions, and when they get to the end, more clarity } \\
\text { - } \text { as to what or where they will go } \rightarrow \text { more missions or choices. } \\
\text { - Display the equation of the line drawn from "planet" to "planet". }\end{array}$ \\
\hline
\end{tabular}




\begin{tabular}{|c|c|}
\hline $\begin{array}{l}\text { Computer } \\
\text { Science }\end{array}$ & $\begin{array}{l}\text { - Buttons are active and hidden - e.g., upper left and main } \\
\text { choice buttons hidden behind instructions and help screen } \\
\text { - Level } 2 \text { - should there be a short pipe under the second-last } \\
\text { OR gate? } \\
\text { - Level } 2 \text { - no 'unsuccessful' message } \\
\text { - Level } 3 \text { - no 'unsuccessful' message } \\
\text { - Level } 5 \text { - incorrect message if choose right-most two taps } \\
\text { (message also appears twice) } \\
\text { - Level } 5 \text { - no 'unsuccessful' message } \\
\text { - Level } 6 \text { - incorrect message if choose either of the } \\
\text { right-most taps } \\
\text { - Level } 6 \text { - no 'unsuccessful' message } \\
\text { - On level 6, above NAND, there is no end to the pipes } \\
\text { - tap colour to green (to match text instructions and feedback from users) } \\
\text { - About screen - bump up the version number (v1.4?, v1.5?) } \\
\text { Teacher Info / Expectations à 'Ontario Curriculum Unit } \\
\text { Planner' should be changed to 'the content and intentions of the } \\
\text { published Ontario curriculum' } \\
\text { - Teacher Info / Prerequisite- same wording as above } \\
\text { - The big grey box at the left with all the mouse-over help - } \\
\text { put this on the right and make it a water tank, and then feed the flow } \\
\text { from this - it would make it a useful part of the metaphor, rather than } \\
\text { a big help box taking up a large part of the screen }\end{array}$ \\
\hline Physics & $\begin{array}{l}\text { - Program locked up at times. } \\
\text { - Instructions are not obvious. } \\
\text { - Screen Resolution problems. } \\
\text { - Labels inconsistent. } \\
\text { - No defined Learning Objects for Case 3. } \\
\text { - Boat can disappear!? } \\
\text { - Better used as a demonstration tool or as a problem solving simulation. } \\
\text { - Cannot teach the concept in isolation from a teacher. }\end{array}$ \\
\hline
\end{tabular}

\section{Discussion}

\section{Evaluation of Learning Object}

\section{Perceived benefit}

The results from this study suggest that learning objects designed and developed using a multicomponent model are viable learning tools for secondary students. Two-thirds of all students felt that learning objects were beneficial, particularly when they had a motivating theme, with visual supports, and interactivity. Independent evidence from experienced and preservice teachers was consistent with student reports. These results are also consistent with previous research on instructional design (e.g., Akpinar \& Hartley, 1996; Bagui, 1998; Druin et al. 1999; Gadanidis et al., 2003; Hanna, Risden, Czerwinski, \& Alexander, 1999; Harp \& Mayer, 1998; Kennedy \& McNaught, 1997; Oren, 1990; Sedig \& Liang, 2006; Stoney \& Wild, 1998). Overall, the learning features incorporated in the development process were well received by students and teachers. 
The technical features considered in the design of these learning objects were ignored by students and teachers. Reusability and accessibility were not mentioned once in the qualitative feedback given, however, the implementation of the learning objects minimized the impact of these features. In other words, each learning object was used by a single grade only and was readily accessible over the web. Reusability, accessibility and metadata may have been more of an issue had teachers born the responsibility of selecting objects from a large database. It is unlikely, though, that students will ever be preoccupied with technical design features typically addressed by learning objected theorists (Boyle, 2003; Bradley \& Boyle, 2004; Hamel \& Ryan-Jones, 2002; Laurillard, 2002; Littlejohn, 2003; Paquette \& Rosca, 2002; Petrinjak \& Graham, 2004; Polsani, 2003; Siqueira et al., 2004) simply because teachers select the learning objects to be used in the classrooms. Once a learning object is selected, challenges based on reusability, accessibility, and metadata are essentially eliminated.

\section{Quality of learning object}

The results from this paper suggest that four of the thirteen learning quality categories (Table 3) are particularly important in terms of learning object quality and benefit: usefulness, clear instructions, organization/layout, and theme/motivation. If the learning object provides clear instructions, is well organized, motivating, and perceived as being useful, secondary students are more likely feel they have benefited from the experience. These results match the qualitative feedback reported by Cochrane (2005) and MacDonald et al. (2005) for higher education students.

Teacher feedback confirmed the impressions reported by students, however, the detail and quality of their suggestions was relatively vague. It is difficult for a teacher to observe the nuances of learning for all students in a limited instructional time. Nonetheless, the teachers in this study were able to get a general sense of the learning objects quality that was consistent with student perceptions.

On the other hand, student feedback on programming bugs was typically vague and unfocussed. Most of the time, students appeared to be trying to learn. The teachers, though, who were the designers of these learning objects, were effective in gathering and providing detailed suggestions on programming changes that needed to me made.

In summary, both student and teacher feedback were essential for examining the quality of learning objects. The student responses regarding learning features provided clear guidelines on what works well: usefulness, clear instructions, organization/layout, and theme/motivation. Teacher feedback provided clear suggestions for improving the consistency and clear presentation of the learning object.

\section{Multi-Component Model}

There are five key conclusions that can be made regarding the multi-component development model used to create learning objects for this study. First, as stated earlier, the learning features were more important to students and teachers than technical features. This result was not predicted by previous literature, where a heavy bias has been placed on more technical issues such as metadata, reusability, and accessibility (e.g., Boyle, 2003; Bradley \& Boyle, 2004; Hamel \& Ryan-Jones, 2002; Laurillard, 2002; Littlejohn, 2003; Paquette \& Rosca, 2002; Petrinjak \& Graham, 2004; Polsani, 2003; Siqueira et al., 2004).

Second, the team approach worked reasonably well in producing five learning objects in a relatively short time period. The experienced teacher proved valuable in selecting topics that were relevant to student needs. It is doubtful that preservice candidates would have been able to accurately anticipate important topics and motivating themes without the guidance of a veteran educator. It should be noted that the use of a Flash/multimedia programmer was also critical - the ob- 
jects could not have been completed without the support of this individual, especially near the final deadline. One modification supported by previous studies (Bradley \& Boyle, 2004; Cochrane, 2005; Krauss \& Ally, 2005; Metros, 2005; MacDonald et al., 2005; Polsani, 2003) would be to have a full time programmer. Preservice teachers were good at forming story lines and PowerPoint simulations of the learning objects, however, learning Flash and its complexities to successfully program a learning object is an onerous task for a preservice teacher candidate. Additionally, last minute programming pressures resulted in a number of "bugs" that might have been avoided with the assistance of a dedicated programmer.

Third, the half day devoted to understanding learners and focussing on effective learning strategies was critical for the success of the learning objects given that the perceived benefit by students was predicated on interactivity, effective visual representations, and a motivating theme. This emphasis on learning is supported by a handful of previous studies (e.g., Bradley \& Boyle, 2004; Cochrane, 2005; Gadanidis et al., 2003; Sedig \& Liang, 2006). That said, 45\% of the students were either neutral or negative with respect to the benefits of the learning object. Given that the primary focus of students and teachers was pedagogy, it might be wise to dedicate even more time to the "understanding the learner".

Fourth, four of the five and half days devoted to team development of the learning object focussed on organization, prototyping, and an extensive feedback cycle to ensure that the learning objects were easy to use and understand. This time was well spent given that students rated clear instructions and organization/layout as two of the most important qualities of the learning object. These findings are consistent with instructional design research (e.g., Baruque \& Melo, 2004; Krauss \& Ally, 2005; MacDonald et al., 2005; Muzio et al., 2003), but have only been formally tested with learning objects in one study (Cochrane, 2005). Nonetheless, even though over $70 \%$ of formal design and development time was spent on clear instructions and organization/layout, these were the two biggest obstacles noted by students in the study. More pilot testing may have improved the instructional guidance offered by learning objects.

Finally, it is clear that a detailed, theoretically-based evaluation tool coupled with teacher focus groups was a critical component in the design and development of learning objects. This component has been noticeably absent in learning object research (Downes, 2003; Krauss \& Ally, 2005). Without the comprehensive analysis of feedback from teachers and students, it would have been challenging to identify key features important to the success of the learning objects.

\section{Caveats}

This study was first attempt to systematically develop learning objects for secondary school students. While the study produced useful information for educators and researchers, there are at least three key areas that could be improved in future research. First, a set of pre and post-test content questions is important to assess whether any learning actually occurred. Second, a more systematic survey requiring students to rate all benefit and quality categories (Tables 2 and 3) would help to provide more comprehensive assessment data. Finally, details about how each learning object is used are necessary to open up a meaningful dialogue on the kinds of instructional wrap that might affect use.

\section{Future Development of Learning Objects}

Based on the results from this study and previous research, there are a number of key suggestions for the future development of learning objects including:

- A dedicated programmer and designer coupled with extensive pilot testing on a wide range of subjects is recommended to ensure clarity of instructions and help, as well as ease of use 
- Considerable time should be devoted to understanding what motivates the learner, as well as the key elements of the learning object that enhance learning

- A comprehensive, theoretically-based evaluation tool is needed to identify critical components that effect the success of learning objects

- Future research should look at actual learning outcomes and the nature of instructional wrap that embraces the learning object

\section{Summary}

The purpose of this study was to examine the quality and perceived benefit of learning objects developed for secondary school students using a multi-component model incorporating both technical and learning based features. Overall, two thirds of the students stated they benefited from using the learning object. Students benefited more if they were comfortable with computers, the learning object had a well organized layout, instructions are clear, and the theme was fun or motivating. Students appreciated the motivating, hands-on, and visual qualities of the learning objects most. While the developmental model used in this study emphasized both technical and learning base features, the latter proved to be more important to teachers and students. Key steps that were beneficial in the development process included a collaborative team approach, understanding the learner, a focus on clear instruction and organization, and using comprehensive, theoretically supported evaluation metric examining the quality and benefits of learning objects.

\section{References}

Acovelli, M., \& Gamble, M. (1997). A coaching agent for learners using multimedia simulations. Educational Technology, 37(2), 44-49.

Agostinho, S., Bennett, S., Lockyear, L., \& Harper, B. (2004). Developing a learning object metadata application profile based on LOM suitable for the Australian higher education market. Australasian Journal of Educational Technology, 20(2), 191-208.

Akpinar, Y., \& Hartley, J. R. (1996). Designing interactive learning environments. Journal of Computer Assisted Learning, 12(1), 33-46.

Albanese, M. A., \& Mitchell, S. A. (1993). Problem-based learning: A review of the literature on its outcomes and implementation issues. Academic Medicine, 68, 52-81.

Atkins, M. J. (1993). Theories of learning and multimedia applications: An overview. Research Papers in Education, 8(2), 251-271.

Bagui, S. (1998). Reasons for increased learning using multimedia. Journal of Educational Multimedia and Hypermedia, 7(1), 3-18.

Baruque, L. B., \& Melo, R. N. (2004). Learning theory and instructional design using learning objects. Journal of Educational Multimedia and Hypermedia, 13(4), 343-370.

Boyle, T. (2003). Design principles for authoring dynamic, reusable learning objects. Australian Journal of Educational Technology, 19(1), 46-58.

Bradley, C., \& Boyle, T. (2004). The design, development, and use of multimedia learning objects. Journal of Educational Multimedia and Hypermedia, 13(4), 371-389.

Brown, J. S., Collins, A., \& Duiguid, P. (1989). Situated cognition and the culture of learning. Educational Researcher, 18(1), 32-42.

Bruner, J. (1983). Child's talk. Learning to use language, Toronto, Canada: George J. McLeod Ltd.

Bruner, J. (1986). Actual minds, possible worlds. Cambridge, MA: Harvard University Press.

Butson, R. (2003). Learning objects: Weapons of mass instruction. British Journal of Educational Technology, 34(5), 667-669. 
Calvi, L. (1997). Navigation and disorientation: A case study. Journal of Educational Multimedia and Hypermedia, 6(3/4), 305-320.

Carroll, J. B. (1990). The Nurnberg funnel. Cambridge, MA: MIT Press.

Carroll, J. M., \& Mack, R. L. (1984). Learning to use a word processor: By doing, by thinking, and by knowing. In J. C. Thomas and M. Schneider (Eds.), Human factors in computer systems. Norwood, NJ: Ablex.

Cochrane, T. (2005). Interactive QuickTime: Developing and evaluating multimedia learning objects to enhance both face-to-face and distance e-learning environments. Interdisciplinary Journal of Knowledge and Learning Objects, 1. Retrieved August 3, 2005 from http://ijklo.org/Volume1/v1p033054Cochrane.pdf

Collins, A. Brown, J. S., Newman, S. E. (1989). Cognitive apprenticeship: Teaching the crafts of reading, writing, and mathematics. In L. B. Resnick (Ed.), Knowing, learning, and instruction (pp. 453-494). Hillsdale, NJ: Erlbaum Associates.

Compton, V., \& Harwood, C. (2003). Enhancing technological practice: An assessment framework for technology education in New Zealand. International Journal of Technology and Design Education, $13(1), 1-26$.

Downes, S. (2003). Design and reusability of learning objects in an academic context: A new economy of education? USDLA Journal: A Refereed Journal of the United States Distance Learning Association, 17(1). Retrieved October 17, 2005 from http://www.usdla.org/html/journal/JAN03_Issue/article01.html

Druin, A., Bederson, B., Boltman, A., Miura, A., Knotts-Callahan, D., \& Platt, M. (1999). The design of children's technology. San Francisco: Morgan Kaufmann Publishers, Inc.

Duval, E., Hodgins, W., Rehak, D., \& Robson, R. (2004). Learning objects symposium special issue guest editorial. Journal of Educational Multimedia and Hypermedia, 13(4), 331-342.

Friesen, N. (2001). What are educational objects? Interactive Learning Environments, 9(3).

Gadanidis, G., Gadanidis, J. \& Schindler, K. (2003). Factors mediating the use of online applets in the lesson planning of pre-service mathematics teachers. Journal of Computers in Mathematics and Science Teaching, 22(4), 323-344.

Gibbons, A. S., Nelson, J. \& Richards, R. (2000). The nature and origin of instructional objects. In D. A. Wiley (Ed.), The instructional use of learning objects: Online version. Retrieved July, 12005 from http://reusability.org/read/chapters/gibbons.doc

Hamel, C. J. and Ryan-Jones, D. (2002). Designing instruction with learning objects. International Journal of Educational Technology, 3(1). Retrieved June 1, 2005 from: http://www.ao.uiuc.edu/ijet/v3n1/hamel/

Hanna, L., Risden, K., Czerwinski, M., \& Alexander, K. J. (1999). The Role of usability in designing children's computer products. In A. Druin (Ed.), The design of children's technology. San Francisco: Morgan Kaufmann Publishers.

Harp, S. F., \& Mayer, R. E. (1998). How seductive details do their damage: A theory of cognitive interest in science learning. Journal of Educational Psychology, 90(3), 414-434.

Jones, M. G., Farquhar, J. D., \& Surry, D. W. (1995). Using metacognitive theories to design user interfaces for computer-based learning. Educational Technology, 35(4), 12-22.

Kay, R. H., \& Knaack, L. (2006). A systematic evaluation of learning objects for secondary school students. Manuscript submitted for publication-

Kennedy, D. M., \& McNaught, C. (1997). Design elements for interactive multimedia. Australian Journal of Educational Technology, 13(1), 1-22.

Klawe, M. M. (1999). Computer games, education and interfaces: The E-GEMS Project. Retrieved January 15, 2000 from http://www.graphicsinterface.org/proceedings/1999/203/

Koehler, M. J., \& Lehrer, R. (1998). Designing a hypermedia tool for learning about children's mathematical cognition. Journal of Educational Computing Research, 18(2), 123-145. 
Kramarski, B., \& Zeichner, O. (2001). Using technology to enhance mathematical reasoning: Effects of feedback and self-regulation learning. Education Media International, 38(2/3).

Krauss, F., \& Ally, M. (2005). A study of the design and evaluation of a learning object and implications for content development. Interdisciplinary Journal of Knowledge and Learning Objects, 1, 1-22. Retrieved August 4, 2005 from http://ijklo.org/Volume1/v1p001-022Krauss.pdf

Lampert, M. (1986). Teaching multiplication. Journal of Mathematical Behaviour, 5, 241-280.

Larkin, J. H. (1989). What kind of knowledge transfers? In L. B. Resnick (Ed.), Knowing, learning, and instruction (pp. 283-305). Hillsdale, NJ: Erlbaum Associates.

Lave, J., \& Wenger, E. (1991). Situated learning: Legitimate peripheral participation. New York: Cambridge University Press.

Laurillard, D. (2002). Design tools for e-learning. In A. Williamson, C. Gunn, A. Young and T. Clear (Eds.). Winds of change in the sea of learning. Proceedings of the 19th Annual Conference of the Australasian Society for Computers in Tertiary Education (ASCILITE), December 8-11, UNITEC, Auckland, New Zealand. Retrieved January 26, 2004, from: http://www.unitec.ac.nz/ascilite/proceedings/papers/key_laurillard.pdf

Littlejohn, A. (2003). Issues in reusing online resources. Journal of Interactive Media in Education, 1, Special Issue on Reusing Online Resources. Retrieved July 1, 2005 from http://wwwjime.open.ac.uk/2003/1/

Lorch, R. F. (1989). Text-signalling devices and their effects on reading and memory processes. Educational Psychology Review, 1(3), 209-234.

MacDonald, C. J., Stodel, E., Thompson, T. L., Muirhead, B., Hinton, C., Carson, B., et al. (2005). Addressing the eLearning contradiction: A collaborative approach for developing a conceptual framework learning object. Interdisciplinary Journal of Knowledge and Learning Objects, 1, 79-98. Retrieved August 2, 2005 from http://ijklo.org/Volume1/v1p079-098McDonald.pdf

Madhumita \& Kumar, K. L. (1995). Twenty-one guidelines for effective instructional design. Educational Technology, 35(3), 58-61.

McGreal, R. (2004). Learning objects: A practical definition. International Journal of Instructional Technology and Distance Learning, 1(9). Retrieved August 5, 2005 from http://www.itdl.org/Journal/Sep_04/article02.htm

McGreal, R., Anderson, T., Babin, G., Downes, S., Friesen, N., Harrigan, K., et al. (2004). EduSource: Canada's learning object repository network. International Journal of Instructional Technology and Distance Learning, 1(3). Retrieved July 24, 2005 from http://www.itdl.org/Journal/Mar_04/article01.htm

McRobbie, C. J., Ginns, I. S., \& Stein, S. J. (2000). Preservice primary teachers' thinking about technology and technology education. International Journal of Technology and Design Education, 10, 81-101.

Metros, S. E. (2005). Visualizing knowledge in new educational environments: A course on learning objects. Open Learning, 20(1), 93-102.

Muzio, J. A., Heins, T., \& Mundell, R. (2002). Experiences with reusable e-learning objects from theory to practice. Internet and Higher Education, 2002 (5), 21-34.

Nielsen, J. (1994). Heuristic evaluation. In J. Nielsen \& R. L. Mack (Eds.), Usability inspection methods. New York, NY: John Wiley \& Sons.

Oren, T. (1990). Cognitive load in hypermedia: Designing for the exploratory learner. In S. Ambron \& K. Hooper (Eds.), Learning with interactive multimedia (pp. 126-136). Washington: Microsoft Press.

Paquette, G., \& Rosca, I. (2002). Organic aggregation of knowledge object in educational systems. Canadian Journal of Learning and Technology, 28 (3). Retrieved July 1, 2005 from http://www.cjlt.ca/content/vol28.3/paquette_rosca.html

Parrish, P. E. (2004). The trouble with learning objects. Educational Technology Research \& Development, 52(1), 49-67. 
Petrinjak, A., \& Graham, R. (2004). Creating learning objects from pre-authored course materials: Semantic structure of learning objects - design and technology. Canadian Journal of Learning and Technology, 30 (3). Retrieved July 1, 2005 from http://www.cjlt.ca/content/vol30.3/petrinjak.html

Plante, J., \& Beattie, D. (2004). Connectivity and ICT integration in Canadian elementary and secondary schools: First results from the Information and Communications Technologies in Schools Survey, 2003-2004. Statistics Canada. Retrieved Aug 29, 2004 from http://www.schoolnet.ca/home/documents/Report_EN.pdf

Polsani, P. R. (2003). Use and abuse of reusable learning objects. Journal of Digital Information, 3(4), Retrieved July 1, 2005 from http://jodi.ecs.soton.ac.uk/Articles/v03/i04/Polsani/

Rehak, D. \& Mason, R. (2003). Chapter 3: Keeping the learning in learning objects. Journal of Interactive Media in Education, 2003 (1). Retrieved July 1, 2005 from http://www-jime.open.ac.uk/2003/1/reuse$\underline{05 . h t m l}$

Savery, J. R., \& Duffy, T. M. (1995). Problem-based learning: An instructional model and its constructivist framework. Educational Technology, 35(5), 31-34.

Sedig, K \& Liang, H (2006). Interactivity of visual mathematical representations: Factors affecting learning and cognitive processes. Manuscript submitted for publication.

Sedighian, K. (1998). Interface style, flow, and reflective cognition: Issues in designing interactive multimedia mathematics learning environments for children. Unpublished Doctor of Philosophy dissertation, University of British Columbia, Vancouver.

Siqueira, S. W. M., Melo, R. N., \& Braz, M. H. L. B. (2004). Increasing the semantics of learning objects. International Journal of Computer Processing of Oriental Languages, 17(1), 27-39.

Sternberg, R. J. (1989). Domain-generality versus domain-specificity: The life and impending death of a false dichotomy. Merrill-Palmer Quarterly, 35(1), 115-130.

Stoney, S., \& Wild, M. (1998). Motivation and interface design: Maximizing learning opportunities. Journal of Computer Assisted Learning, 14(1), 40-50.

U.S. Department of Education, National Center for Education Statistics (2002). Internet Access in U.S. Public Schools and Classrooms: 1994-2002. Retrieved August 30, 2004 from http://nces.ed.gov/programs/digest/d02/tables/dt419.asp

Vygotsky, L. S. (1978). Mind in society. Cambridge, MA: Harvard University Press.

Wiest, L. R. (2001). The role of computers in mathematics teaching and learning. Computers in the Schools, 17(1/2), 41-55.

Wiley, D. A. (2000). Connecting learning objects to instructional design theory: A definition, a metaphor, and a taxonomy. In D. A. Wiley (Ed.), The instructional use of learning objects: Online version. Retrieved July, 1, 2005, from http://reusability.org/read/chapters/wiley.doc

Wiley, D., Wayers, S., Dawson, D., Lambert, B., Barclay, M., \& Wade, D. (2004). Overcoming the limitations of learning objects. Journal of Educational Multimedia and Hypermedia, 13(4), 507-521.

Williams, D. D. (2000). Evaluation of learning objects and instruction using learning objects. In D. A. Wiley (Ed.), The instructional use of learning objects: Online version. Retrieved July 1, 2005 from http://reusability.org/read/chapters/williams.doc

Zammit, K. (2000). Computer icons: A picture says a thousand words. Or does it? Journal of Educational Computing Research, 23(2), 217-231. 


\section{Appendix A - Learning Object Survey - Students}

1. The learning object has some

\begin{tabular}{|c|c|c|c|c|c|c|}
\hline $\begin{array}{c}\text { Strongly } \\
\text { Disagree } \\
1\end{array}$ & $\begin{array}{c}\text { Dis- } \\
\text { agree } \\
2\end{array}$ & $\begin{array}{c}\text { Slightly } \\
\text { Disagree } \\
3\end{array}$ & $\begin{array}{c}\text { Neutral } \\
4\end{array}$ & $\begin{array}{c}\text { Slightly } \\
\text { Agree } \\
5\end{array}$ & $\begin{array}{c}\text { Agree } \\
6\end{array}$ & $\begin{array}{c}\text { Strongly } \\
\text { Agree } \\
7\end{array}$ \\
\hline
\end{tabular}
benefit in terms of providing me with another learning strategy/another tool.

2. I feel the learning object did benefit my understanding of the subject matter's concept/principle.

3. I did not benefit from using the learning object.

I am interested in using the learning object again.
1

1

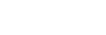

2

1

1

2

3

4

5

6

7

5. Do you think you benefited from using this particular learning object? Do you think you learned the concept better? Do you think it helped you review a concept you just learned? Why? Why not.

6. You used a digital learning object on the computer. Tell me about this experience when you used the object.

a) What did you like? (found helpful, liked working with, what worked well for you)

b) What didn't you like? (found confusing, or didn't like, or didn't understand)
1. The learning object has benefit in terms of providing students with another learning strategy in my classroom.

2. The learning object did benefit my students in terms of their understanding of the concept/principle explored in the learning object.

3. I would be interested in using the learning object again in my class.

4. There would have been more success with the learning object had it been implemented during the proper time within the unit.

5. Students were interested in using the learning object again.

\begin{tabular}{|c|c|}
\hline Strongly & Dis- \\
Disagree & agree \\
1 & 2 \\
\hline
\end{tabular}

$\begin{array}{lllllll}1 & 2 & 3 & 4 & 5 & 6 & 7\end{array}$

1

2

3

4

5

6

7

12

3

4

5

6

7

\section{1}

2

3

4

5

6

7

6. What did students like? What worked? What did they learn?

7. What didn't students like? What didn't work out well? What didn't they learn? 


\section{Biographies}

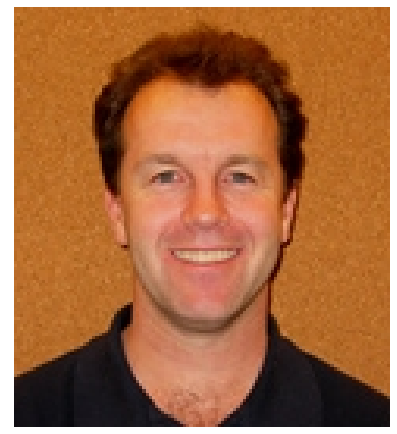

Robin Kay, Ph.D. is an Assistant Professor in the Faculty of Education at the University of Ontario Institute of Technology. He has published over 20 articles in the area of computers in education, presented numerous papers at 10 international conferences, refereed three prominent computer education journals, and taught computers, mathematics, and technology for over 15 years. Current projects include research on laptop use in teacher education, discussion board use, electronic evaluation of teacher education programs, and factors that influence how students learn with technology.

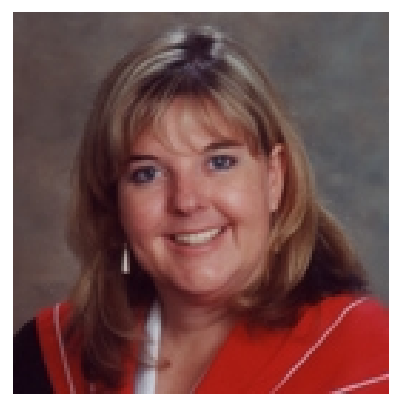

Liesel Knaack, Ph.D. is an Assistant Professor in the Faculty of Education at the University of Ontario, Institute of Technology. Her research interests are in the areas of design, development and evaluation of learning objects, effective integration of computers in the curricula, instructional design of digital learning environments and the process of change in implementing technology use at institutions of higher education. Current projects include laptop use in preservice education programs, online discussions and digital performance appraisals. 